\title{
Chapter 2 \\ Intercultural Education \\ for the Twenty-First Century: \\ A Comparative Review of Research
}

\author{
Chrysi Rapanta and Susana Trovão
}

\subsection{Introduction}

Based on the assumption that globalization should not imply homogenization, it is important for education to promote dialogue and intercultural understanding. The first appearance of the term 'intercultural education' in Europe dates back to 1983, when European ministers of education at a conference in Berlin, in a resolution for the schooling of migrant children, highlighted the intercultural dimension of education (Portera 2008). One of the mandates of intercultural education is to promote intercultural dialogue, meaning dialogue that is "open and respectful" and that takes place between individuals or groups "with different ethnic, cultural, religious and linguistic backgrounds and heritage on the basis of mutual understanding and respect" (Council of Europe 2008, 10). Such backgrounds and heritages form cultural identities, not limited to ethnic, religious and linguistic ones, as culture is a broader concept including several layers such as "experience, interest, orientation to the world, values, dispositions, sensibilities, social languages, and discourses" (Cope and Kalantzis 2009, 173). As cultural identities are multi-layered, so is cultural diversity, and therefore it becomes a challenge for educators and researchers to address it (Hepple et al. 2017). Referring to Leclercq (2002), Hajisoteriou and Angelides (2017, 367) argue that "intercultural education aims to stress the dynamic nature of cultural diversity as an unstable mixture of sameness and otherness." This challenge relates to the dynamic concept of culture itself, as socially constructed, and continuously shaped and reshaped through communicative interactions (Holmes et al. 2015).

Faced with this fluidity of cultural identities, several European research initiatives, such as DIALLS, have focused on intercultural dialogue as a vivid experience not limited to knowing about other ethnical/religious/linguistic identities, but including the engagement in a being with relationship with any other person having their own

C. Rapanta $(\bowtie) \cdot$ S. Trovão

NOVA University, Lisbon, Portugal

e-mail: chrysi.rapanta@fcsh.unl.pt 
cultural identities. This twofold consideration of otherness and engagement forms the basis of the approach adopted by DIALLS with regard to intercultural dialogue and informs the project's place within the European context of intercultural education. The goal of this chapter is to analyze the intercultural education research literature, investigating its most salient theoretical operationalizations throughout the years, and identifying challenges and gaps that still need to be addressed by current and future projects.

\subsection{Theoretical Operationalizations of Intercultural Education Research}

\subsubsection{Intercultural Learning}

Under a broad understanding, intercultural learning is about "how we come to understand other cultures and our own through interaction, how we learn and communicate in cultural contexts, and how we learn culturally" (Jin and Cortazzi 2013, 1; emphasis added). Of the three key concepts mentioned, i.e. 'interaction', 'cultural context' and 'learning culturally', the first relates to means (dialogue), the third to consequences (culturally learning competence), while understanding and awareness of the cultural context is most related to intercultural learning understood strictly. Such cultural context awareness is mainly subjective, i.e. based on and including one's own world views (Bennett 2009). In this sense, an important related concept to intercultural learning is "cultural self-awareness," i.e. recognizing the ways in which one's "own worldview is reflective to some extent of the group of people with whom they interact" (Bennett 2009, S4).

Another related concept to cultural awareness is cultural sensitivity. According to the Developmental Model of Intercultural Sensitivity (DMIS) (Bennett 1993), people seem to move through six possible orientations while learning culturally: three ethnocentric orientations (Denial, Defense, Minimization), where one's own culture is experienced as central; and three ethnorelative orientations (Acceptance, Adaptation, Integration), where one's culture is experienced in the context of other cultures. The underlying assumption of the DMIS model is that as one's experience of cultural diversity becomes more sophisticated, in the movement from ethnocentrism towards ethno relativism, one's potential for demonstrating intercultural competence also increases (Hammer et al. 2003). To further highlight this passage from sensitivity to competence, Hammer et al. (2003) use the term intercultural sensitivity to refer to "the ability to discriminate and experience relevant cultural differences", and the term intercultural competence to mean "the ability to think and act in interculturally appropriate ways" (p. 422). The latter is further explained below. 


\subsubsection{Intercultural Competence}

According to Otten (2003), intercultural learning leads to intercultural competence. Intercultural competence is largely associated with social, culturally learnt competence, such as the ability for empathy and perspective taking (Busse and Krause 2015). It can be defined as "the ability to interact effectively and appropriately in intercultural situations, based on one's intercultural knowledge, skills and attitudes" (Deardorff 2006, 247). To these components, Deardorff (2006) and others (e.g. Busse and Krause 2015) add the ability for reflection, which includes the display of flexibility and empathy. Deardorff's definition of intercultural competence is different from the Intercultural Communicative Competence (ICC) which mainly refers to the ability of communicating effectively in a foreign language (Byram 2012).

In its initial conceptualization by Byram (1997), intercultural competence (IC) comprised a diverse set of skills and attitudes, including the knowledge of contents about the others' cultures (savoirs), the skills to interpret and relate (savoir comprendre), the skills to discover and/or interact (savoir apprendre/faire), the attitudes of being with others (savoir être), and the attitude of critical cultural awareness (savoir s'engager), which refers to "relativisation of one's own and valuing of others' meanings, beliefs and behaviours" (p. 35). However influential this description of intercultural (communicative) competence has been, it should not be ignored that it was proposed in the field of foreign language teaching to describe effective social interaction with someone from a different country. From this perspective, especially meaningful for foreign language education contexts, the differences between IC and ICC are difficult to identify, rendering Byram's proposal limited as regards the 'savoirs' or know-what aspects of intercultural communication, which need to refer to a particular culture or cultures. This limitation is overcome with an 'etic' view of intercultural dialogue, as explained below.

\subsubsection{Intercultural Dialogue}

Intercultural dialogue is broadly defined as "the exchange of views and opinions between different cultures" (European Commission n.d.). In this broad definition, a distinction between the emic (i.e. culture-specific) and etic (i.e. culture-general) aspects (Triandis 1994) of cultural awareness or sensitivity is implied, with a clear focus towards the latter. Moreover, cultures are perceived as 'containers' and intercultural dialogue "as the interaction of stable and cohesive units which mutually accept and appreciate one another but which remain closed to mutual influences" (Gropas and Triandafyllidou 2011, 413). Therefore, a focus on the 'etic' aspects of culture as implied in the general definitions of intercultural dialogue often found in European policy documents (Lähdesmäki et al. 2020) weakens, if not cancels, the 'inter' (Portera 2008) dynamics of dialogue and their implied transition of knowledge and learning as part of an emic negotiation (Allmen 2011). 
A culture-specific approach to intercultural dialogue must take into consideration both individuals' objective and subjective cultures. Objective culture, also known as 'Big-C' culture, refers to "the set of institutional, political and historical circumstances that have emerged from and are maintained by a group of interacting people" (Bennett 2009, S3). Subjective culture, also known as 'little-c' culture, refers to the "worldview of people who interact in a particular context" (Bennett 2009, S3). The importance of taking into consideration both types of culture when teaching or engaging in intercultural dialogue is explained by educational researchers O'Connor and Michaels (2007, 275), commenting on Wells (2007):

in the process of language acquisition, children acquire their culture's implicit sign system. As signs are internalized, so is the 'dialogicality' or meaning-making stance of the home culture internalized. In this way, children from different cultures, different social classes, or different school environments take on more than language; they take on different values or 'meaning potentials' and expectations relating to making meaning in dialogue with others or in thinking on one's own.

Based on the above, we cannot speak of intercultural dialogue without taking into consideration the meaning negotiation dynamics between at least two individuals representing different, both objective and subjective, cultural backgrounds at that moment of interaction. Further extending this assumption, it is those interaction dynamics, and their analysis, that define whether a dialogue is inter-cultural, and not any a priori definition of individuals' static characteristics before entering the dialogue. This view is adopted by the recently developed field of intercultural pragmatics, where culture is seen "as a socially constituted set of various kinds of knowledge structures that individuals turn to as relevant situations permit, enable and usually encourage" (Kesckes 2014,4). These knowledge structures can be of various types, as previously explained, comprising specific culture knowledge (knowwhat), skills (know-how), attitudes (know-to-be) and behaviors (know-to-engage), all of which are also important components of intercultural competence (Byram 1997; Barrett 2012). A common paradox in the sociocognitive learning literature (Sfard 2008) emerges: from an acquisition perspective, intercultural competence is a prerequisite for engaging in intercultural dialogue; from a participation perspective, intercultural dialogue fosters intercultural competence.

For DIALLS researchers (e.g. Maine et al. 2019) and other educational researchers, the dialogue participation and engagement perspective prevails. Following Buber's (1955) perspective on genuine dialogue, a 'simple' conscious awareness of the other or others and "the intention of establishing a living mutual relation between himself and them" (p. 22) is enough for someone to engage in intercultural dialogue in its broader emic sense. Nonetheless, as dialogue analysts would counter-argue, such awareness of the others and their intentions in dialogue are not at all simple to develop, from the participants' point of view, and to detect, from the analysts' point of view. As Kesckes $(2014,11)$ points out:

To interpret an utterance properly, the interlocutor has to arrive at an understanding not only of its communicative function of utterances but also of the communicative agenda of his/her dialogue pattern, i.e., what s/he really wants to achieve in the dialogue. 
Thus, since understanding of the content but also and especially of the communicative function of the others' utterances is highly problematic to achieve and to analyze, the study of intercultural dialogue in action, and not as a pre-defined or taken-for-granted entity, is itself a good starting point.

To summarize this theoretical introduction, the basis of intercultural education is intercultural dialogue (UNESCO 2009), which, in its turn, may or may not satisfy the intercultural education standards and goals, depending on the degree, depth or quality of participants' intercultural learning which leads to the so-called intercultural competence. At the same time, intercultural competence perceived as sensitivity and adaptability to different cultural contexts may be enhanced through people's engagement in dialogue and learning with and from each other. The three interrelated concepts, namely dialogue, learning and competence are important pillars of intercultural education, as policy documentation analysis shows (Lähdesmäki et al. 2020; see also Chapter 4 in this volume). However, it is not yet clear how the three concepts have thus far been operationalized and assessed by empirical educational studies.

\subsection{The Present Study}

In the face of the current fluid cultural realities the world over, and the need for a continuously adapting and adaptive education, the question of whether and how educational research has changed its conception and operationalization of intercultural education emerges as highly relevant. To address this question, a systematic review of empirical research is presented, aiming to reveal the predominant objectives, methods, contents, and risks of teaching and learning interculturally in the last two decades. Another aim shall be to identify whether there are any emerging differences by comparing research conducted in the beginning, middle, and end of the studied period (2000-2019). The chapter ends with recommendations regarding the facing challenges of contemporary educational systems struggling with the challenges of globalization and inclusion.

\subsubsection{Research Questions}

The following aspects/questions were taken into account when looking at intercultural education research initiatives described in the selected literature:

a. Which are the main explicit goals of intercultural education when operationalized through concrete programs, interventions or research initiatives? Have those goals changed over the years? 
b. Do those programs, interventions, initiatives include students interacting with different objective or subjective cultures or do they limit themselves to students learning about different cultures?

c. Do those programs, interventions, initiatives include a clear qualitative and/or quantitative assessment of such culture or intercultural learning? If yes, what is being assessed and how?

\subsubsection{Sampling}

The search for sources was carried out in the Scopus database by Elsevier for its strictness regarding quality criteria of published research. The first search performed had as unique criterion the inclusion of "intercultural education" or "intercultural learning" in the title of the document (Note: the terms "intercultural competence" and "intercultural dialogue" were not selected as keywords due to the specific meaning intended for the first, i.e. related to foreign language contexts, and the broad meaning of the second, i.e. as a general policy and not as educational praxis). This search resulted in 514 documents. After limiting the search to (a) documents published between 2000 and 2019, (b) the subject areas of Social Sciences, Arts and Humanities, and Psychology, and (c) documents written in English, search results were limited to 370 documents including journal articles, books, book chapters, and conference proceedings.

After this initial search, three screening phases followed. The first was an "abstract only" screening, during which 220 documents referring to theoretical studies and not reporting on applied or empirical research were excluded. The 150 documents left went through a second, "full text" screening, during which documents not reporting directly on the study of intercultural education/learning/competence either as a process or as an outcome (e.g. studies focusing on the need for intercultural education as a policy without describing its practice) were excluded. This second screening phase resulted in 80 documents. Finally, a third screening focused only on journal articles, due to the difficulty in finding the full texts of several book chapters and conference proceedings papers. The main exclusion criterion for this final screening was studies carried out in the general context of intercultural/multicultural education but without defining the goals and/or scope in terms of dialogue and/or learning and/or intercultural competence development (e.g. studies exclusively focusing on foreign language learning, or studies describing intercultural education in general without defining any concrete aspects, or studies only describing students' or teachers' perceptions of a course or policy). Moreover, as the focus of this study is on the experience of intercultural education defined as intercultural dialogue, learning, competence or similar, we were not interested in what international educational systems offer. We were rather interested in identifying how intercultural education is operationalized in terms of its goals, methods, and contents, and whether this operationalization has changed throughout the years. The result of 


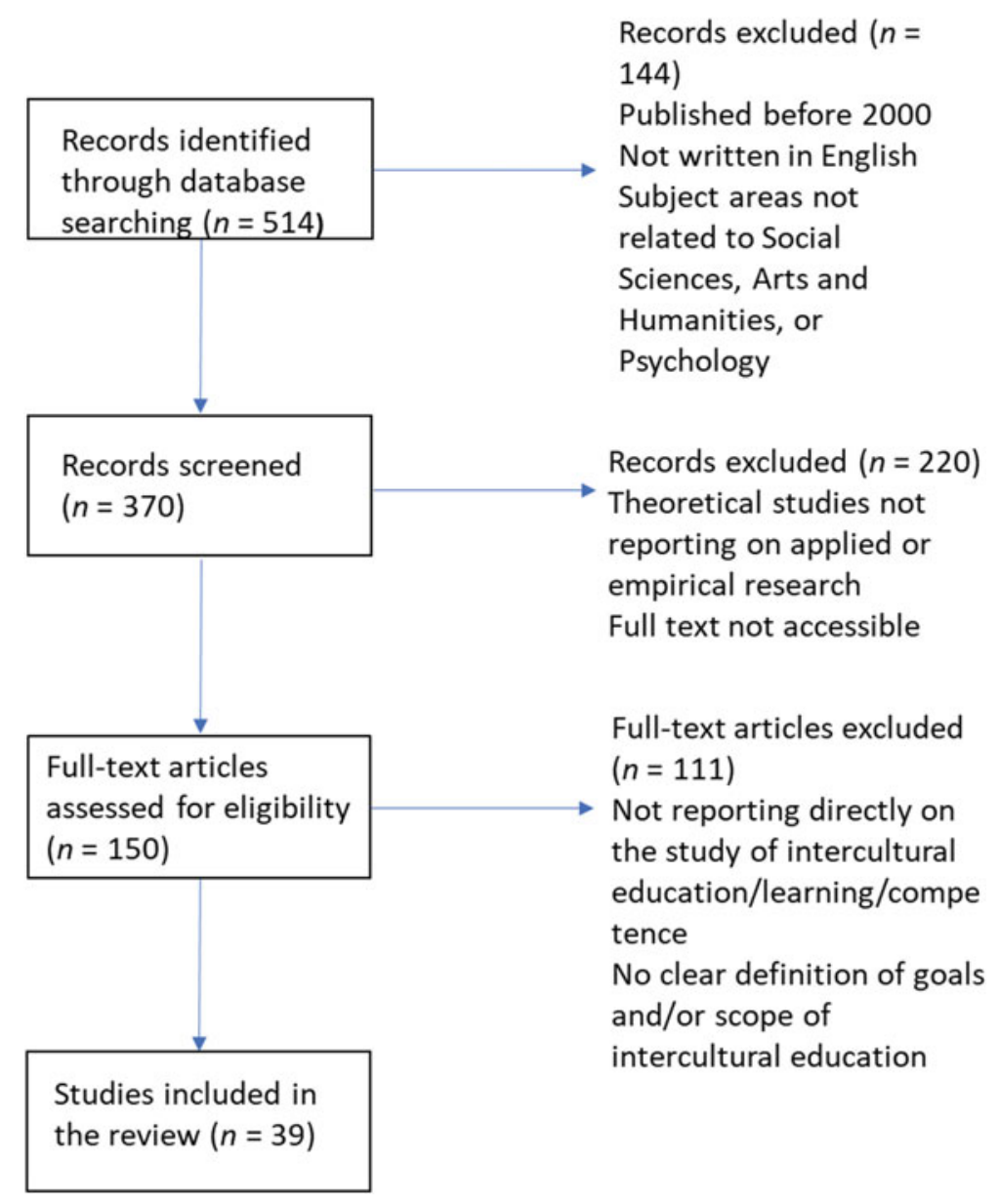

Fig. 2.1 The review sample selection process

this final screening was 39 journal articles, which formed the final review sample. Figure 2.1 shows the search and screening process.

\subsection{Findings}

\subsubsection{Demographic Characterization of the Sample}

Of the 39 studies included in the literature review, eight focused on Australia, either as host or as guest country, six on the United Kingdom, six on the United States of America, four on Germany, four on Italy, and the rest on other countries such as Spain, 
China, the Netherlands, and Canada. Five studies focused on primary school students, six on secondary school, 24 on university students, and the remaining four focused on post-graduate/professional education. Among the studies focusing on university students, five had pre-service teachers as participants, whereas another five of the rest of the studies focused on both students and teachers. Finally, regarding the studies' context, the largest number (eleven studies) took place as part of an international exchange/mobility/work abroad program, ten implemented a particular intervention aimed at enhancing participants' intercultural communication/learning skills such as film watching or dramatic performance, eight were carried out in "natural" classroom environments with a multicultural or intercultural focus, five focused on transnational higher education classrooms, and five implemented some type of telecollaboration between countries. The details of the reviewed studies are presented in Fig. 2.2.

\subsubsection{Chronological Progress in the Conceptualization of Intercultural Education}

The first research question was about identifying the concrete goal(s) through which intercultural education was operationalized in the reviewed studies, and whether there was any change in this operationalization throughout the years. A first observation pertains to the number of studies in the review and their chronological arrangement. A main criterion of inclusion in the sample was the degree to which intercultural education goals were somehow operationalized in the studies, and not remaining vague, undefined or even left implicit, which was quite often the case. It was also common that the studies focused on theoretical or policy-making aspects of intercultural education without any interventional or empirical aspect of assessing its components and goals. This led to quite a reduced sample of 39 studies published after the year 2000. It is noteworthy that the vast majority (36 out of 39 studies) were published from 2010 onwards, and the number of publications doubled after 2015. These differences in the number of studies focusing on some type of operationalization and assessment or improvement of intercultural education goals and outcomes probably reveal an increase in the felt need for this type of focus in recent years.

Of the 16 studies published between 2000 and 2015, 56\% operationalized intercultural education goals in terms of intercultural competence, mainly influenced by Michael Byram's theory of ICC. The other $44 \%$ opted for the use of intercultural learning, with one study (Martin and Griffiths 2014) adopting Mezirow's (2000) transformative learning theory as main reference and six other studies focusing on different aspects/factors of learning such as cultural dissonance (Allan 2003), intercultural adaptation (Gill 2007), and (self-)reflexivity (Donelan 2010; Holmes et al. 2015). Studies published after 2016 present a different image, as shown in Table 2.1. A large majority (44\%) of these focus on intercultural learning, sometimes equated to intercultural dialogue, whereas the rest is divided between intercultural competence $(26 \%)$ and other definitions (30\%), as follows: intercultural (self-)awareness (Brooks 


\begin{tabular}{|c|c|c|c|c|}
\hline Authors \& Date & Country & Students' Grade & Target group & Context \\
\hline Allan (2003) & Netherlands & secondary & students & Multicultural classroom \\
\hline O'Dowd (2003) & Spain \& UK & university & students & International telecollaboration \\
\hline Gill (2007) & China (UK) & university & students & Transnational higher education \\
\hline Donelan (2010) & Australia & secondary & students & $\begin{array}{l}\text { use of drama as an instrument for intercultural } \\
\text { sensibilization }\end{array}$ \\
\hline Baraldi (2012) & Italy & secondary & both & Italian as a Second Language classroom \\
\hline Lee (2012) & Spain (USA) & university & students & $\begin{array}{l}\text { use of blogs and ethnograhic interviews to native } \\
\text { speakers }\end{array}$ \\
\hline Chao (2013) & Taiwan & university & students & use of films as part of an EFL course \\
\hline King \& al. (2013) & USA & university & students & $\begin{array}{l}\text { not a particular context - the authors were interest } \\
\text { in cultural identities and experiences in their broac }\end{array}$ \\
\hline Ari \& Laron (2014) & Israel & university & students & Transnational higher education \\
\hline Martin \& Griffiths (2014) & $\begin{array}{l}\text { UK (Gambia \& } \\
\text { India) }\end{array}$ & beyond university & teachers & Work abroad \\
\hline Santos et al. (2014) & Portugal & primary & both & Intercultural communication course \\
\hline Borghetti et al. (2015) & Italy & university & students & International exchange/mobility program \\
\hline Busse \& Krause (2015) & Germany & university & students & Intercultural communication course \\
\hline Campbell \& Walta (2015) & Australia & pre-service teachers & students & Work abroad \\
\hline Holmes et al. (2015) & UK \& Italy & university & both & International exchange/mobility program \\
\hline Lau (2015) & Canada (Taiwan) & primary & students & International telecollaboration \\
\hline Brooks \& Pitts (2016) & USA (Singapore) & university & students & International telecollaboration \\
\hline Tonkin \& Coudray (2016) & Australia (Germany) & university & students & International exchange/mobility program \\
\hline Wilbur (2016) & $\begin{array}{l}\text { USA (Italy \& } \\
\text { Estonia) }\end{array}$ & university & students & International exchange/mobility program \\
\hline Frimberger (2016) & Scotland & university & students & $\begin{array}{l}\text { use of drama as a methad for "strangeness" } \\
\text { experiences narration and reflection }\end{array}$ \\
\hline Bedekovic (2017) & $\begin{array}{l}\text { Croatia, Serbia, } \\
\text { Bosnia- } \\
\text { Herzegovina, }\end{array}$ & pre-service teachers & students & Development of an intercultural curriculum \\
\hline Cloonan \& al. (2017) & Australia & beyond university & teachers & autobogrophical storytelling \\
\hline Grimminger-Seidensticker \& Möhwald (2017) & Germany & secondary & students & $\begin{array}{l}\text { physical education lessons including experiences of } \\
\text { strangeness (e.g playing soccer with different objec }\end{array}$ \\
\hline Hernandez-Bravo et al. (2017) & Spain & primary & students & Development of an intercultural curriculum \\
\hline Chan et al. (2017) & $\begin{array}{l}\text { Hong Kong \& } \\
\text { Sweden }\end{array}$ & beyond university & students & International telecollaboration project \\
\hline Hajisoteriou \& Angelides (2017) & Cyprus & primary & both & collaborative art-making \\
\hline Hepple et al. (2017) & Australia & pre-service teachers & students & International exchange/mobility program \\
\hline Bozdag (2018) & Australia (Malaysia) & secondary & both & International telecollaboration project \\
\hline Mitchell \& Paras (2018) & Canada (India) & university & students & Transnational higher education \\
\hline Senyshyn (2018) & USA & university & students & Transnational higher education \\
\hline Varga-Dobai (2018) & USA & pre-service teachers & students & cultural selfie: arts-based self-potrtait \\
\hline Mesker et al. (2018) & $\begin{array}{l}\text { Netherlands (UK, } \\
\text { South Africa, }\end{array}$ & pre-service teachers & students & Work abroad \\
\hline Dai \& Garcia (2019) & China (Australia) & university & students & Transnational higher education \\
\hline Piipponen \& Karlsson (2019) & Scotland, Europe) & primary & students & storycrafting method (use of narrative scenarios) \\
\hline Borhaug \& Weringer (2019) & Europe & secondary & students & Multicultural summercamp \\
\hline Dorsett \& al. (2019) & Australia & university & students & International exchange/mobility program \\
\hline Hyett \& al. (2019) & Australia & university & students & virtual learning activity \\
\hline Hessel (2019) & Germany (UK) & university & students & International exchange/mobility program \\
\hline O'Brien et al. (2019) & Ireland & beyond university & students & Work abroad \\
\hline
\end{tabular}

Fig. 2.2 Demographic characterization of the reviewed studies

and Pitts 2016; Bedeković 2017; Varga-Dobai 2018; Børhaug and Weyringer 2019), intercultural adjustment (Dai and Garcia 2019), and finally definitions referring to a broader sense of intercultural competency, literacy or even education, often defined as a 'transcultural' competence (Frimberger 2016; Tonkin and Coudray 2016; Hajisoteriou and Angelides 2017; Hyett et. al. 2019). The Fisher's exact text of independence between year of publication (i.e. before or after 2015) and main intercultural education goal (i.e. intercultural competence, learning, or other) was significant $(p=0.03)$. See Table 2.2 for the corresponding cross-tabulation. 


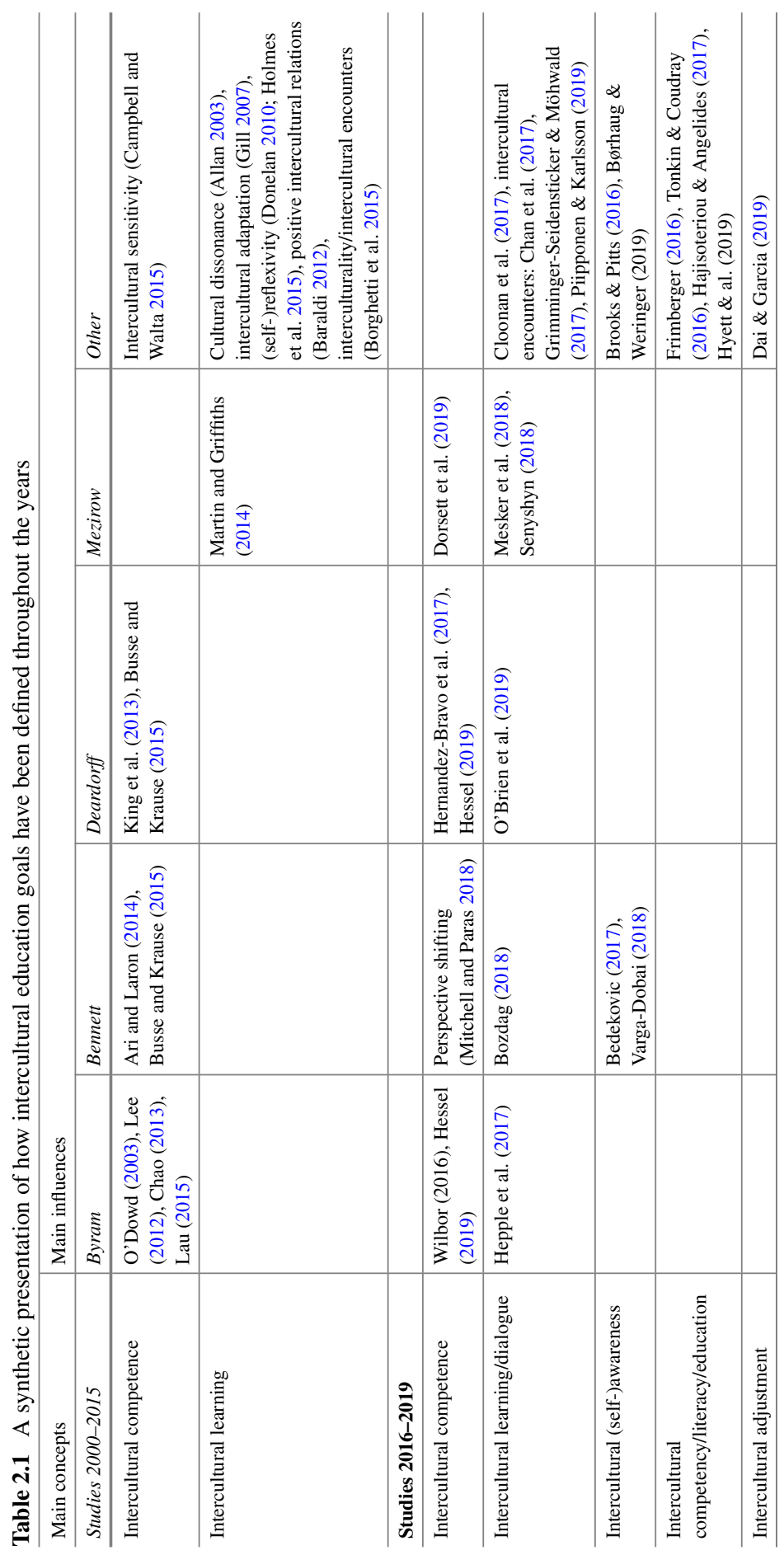


Table 2.2 Cross-tabulation of year of publication and main operationalized goal

\begin{tabular}{l|l|l|l|l}
\hline Year & Intercultural competence & Intercultural learning & Other & Total \\
\hline $2000-2015$ & 9 & 7 & 0 & 16 \\
\hline $2016-2019$ & 6 & 10 & 7 & 23 \\
\hline Total & 15 & 17 & 7 & 39 \\
\hline
\end{tabular}

\subsubsection{Ways of Operationalizing Intercultural Education}

As an answer to the second research question, i.e. whether authors have focused on learning about versus interacting with other cultures, the latter was predominant in the analyzed sample, although manifested in different forms, as explained below.

Cultural self-awareness or 'cultural sensitivity' refers to the degree to which individuals are able and disposed to reflect on their own cultural identities, to identify any dissonances between them, and to understand the origins of the same (i.e. whether consciously or unconsciously acquired). In the analyzed sample, cultural self-awareness was studied both as an intra-personal and as an inter-personal process. Examples of studies that adopted the former include Varga-Dobai's (2018) study with pre-service teachers applying the 'cultural selfie' technique as a way of exploring their own 'funds of knowledge', and Mesker et al.' s (2018) study, again with preservice teachers, where personal biographies and visual metaphors of intra-personal development helped reveal their learning mechanisms of identification, reflection and transformation. When applied in inter-personal contexts, cultural self-awareness can easily be replaced by interpersonal/intercultural awareness and reflexivity. Indeed, several studies showed that this type of reflective experience usually takes place through encounters with others. For instance, Hepple et al. (2017) describe the critical cultural self-examination and 'multicultural awakening' stimulated by the immersion experience of ten Australian pre-service teachers in Malaysian culture. Mitchell and Paras (2018) describe how the experience of intercultural encounters between Canadian and Indian university students caused the former to shift cultural perspective and to question their values, beliefs, and self-concept. In another study, with secondary school students, Børhaug and Weyringer (2019) describe how European summercamp activities led participants to an indirect experience of the stigmatized position of the other and stimulated critical and empathic reflections on social justice and to greater awareness. Thus, reflecting on the experience of others and with others often comes hand-in-hand with cultural self-awareness and is, as Bennett (2009) argues, the precursor of intercultural learning.

For such a personal experience to be transformed into knowledge, an active/reflective dialectic between intention and extension of experience is necessary, as Kolb (2015) argues. Intention refers to the internal reflection preceding or accompanying action, whereas extension refers to the action itself, i.e. the active external manipulation of the external world (Kolb 2015, 67). This dynamic, dialectical basis of knowledge creation also applies to intercultural learning, which also explains why some authors have characterized it as transformative learning (Martin 
and Griffiths 2014; Mesker et al. 2018; Senyshyn 2018; Dorsett et al. 2019). During the process of transformation, which follows reflection, the individual "experiences profound changes in their existing practices", which usually results in "a new role or new identity" (Mesker et al. 2018, 56). Therefore, from this perspective, for individual competence or learning to be achieved, a manifestation of transformation is necessary in how individuals perceive themselves, others, and the world as a whole. For some authors in the analyzed sample, this transformation is manifested simply as a change of perspective from a more ethnocentric towards a more ethnorelativist worldview, following Bennett's (1993, 2009) theory. For others, transformation is or can be even more holistic, and includes a continuous adaptation to new realities, new perspectives, and new 'others' and 'otherness/-es' encountered both outside and within oneself. For instance, Frimberger (2016) uses drama as a method to stimulate 'strangeness' experiences with university students and help them acquire a collective understanding of the "transcultural, in-flux and subjective dimensions of intercultural encounters" (p. 133). Hajisoteriou and Angelides (2017) present a method of collaborative art-making as a way for primary school students to empathize with each other's emotions, within a context of civic efficacy, democratic agency, and friendship promotion.

\subsubsection{Main Methods Used, Findings and Considerations}

Regarding the third research question, i.e. the studies' main methods and findings, the analysis showed that a large majority of the sample (34 out of 39 studies) used qualitative methods of data collection and analysis, three used mixed methods (questionnaire and interview), and only two opted for quantitative methods (closed-ended questionnaires). From the studies that implemented qualitative methods, seven used ethnographic and narrative research methods, 13 used interviews, either alone or in combination with other methods, three used some type of transcribed classroom interaction analysis, and 11 studies used other qualitative analysis methods such as analysis of diaries, blog entries, written reflection or fieldnotes.

In terms of the main findings of the reviewed studies, only two of them (Santos et al. 2014; O'Brien et al. 2019) report an increase of culture-specific knowledge among their main outcomes. Most studies focus on the experiential aspects of intercultural learning, mentioning the value of: 'embodied' experiences (Donelan 2010; Tonkin and Coudray 2016; Frimberger 2016), 'immersion', 'boundary' and 'belonging' experiences (Hepple et al. 2017; Mesker et al. 2018; Dai and Garcia 2019), or even the concrete experience of the 'stigmatised position of the other' (Børhaug and Weyringer 2019). Other experiential and affective aspects were also highlighted: cultural/cognitive dissonance (Allan 2003; Mitchell and Paras 2018), non-essentialist engagement (Holmes et al. 2015), enacted understanding of the Other (Gill 2007), and mutual enrichment (Bedeković 2017). For such experiential or even transformative learning to take place, a disorienting dilemma (Senyshyn 2018), contradiction (Baraldi 2012), or out-of-comfort-zone experiences (Hyett et al. 2019) 
are often necessary, while Martin and Griffiths (2014) stress the value of dialogue and critical reflection on those same experiences. The teachers' role (Piipponen and Karlsson 2019) and tension/discomfort balance (Grimminger-Seidensticker and Möhwald 2017; Mitchell and Paras 2018) are also reported as essential for successful intercultural learning.

When it comes to findings related to intercultural competence, such as acquisition of knowledge, skills, and attitudes, several studies identify a gradual acquisition and improvement of skills (Chao 2013; Santos et al. 2014; Wilbur 2016) and attitudes, namely ethnorelativism (Campbell and Walta 2015), empathy (HernandezBravo et al. 2017), or understanding of cultural diversity (Busse and Krause 2015). However, other studies revealed problems in the development of students' intercultural competence. For instance, Ari and Laron (2014) found that encounters with 'others' during mixed-education (Arab-Jewish) college experience positively influenced the multicultural attitudes of participants, but only at a low percentage (11\%). Another not-so-positive finding is reported by Lau (2015), who mentions the difficulty of disrupting children's ingrained stereotypes of migrants/refugees, and their tendency to be attracted more by the 'exotic' customs and festivals rather than deeper understandings. Students' superficial understanding of culture which remained at a traditions-sharing level is also reported by Bozdağ (2018) in his study with adolescents.

Finally, when it comes to the main challenges identified by the reviewed studies, several authors have considered the influence of national culture on education, especially on policy makers' intercultural perceptions (Allan 2003; Bedeković 2017; Hernandez-Bravo et al. 2017; Bozdağ 2018). Other studies highlight limitations in the use of the concept 'culture' to refer only to a national identity, and its consequences on students' intercultural learning outcomes (Bozdağ 2018; Hessel 2019). Studies also highlight the teachers' role within intercultural education initiatives, notably the need for educational support for cross-system transitions (Dai and Garcia 2019) and the importance of teacher education (Senyshyn 2018). Cloonan et al. (2017) further argue that teachers' exposure to intercultural learning techniques does not guarantee an increase in their capacity to deal with interculturality in their classrooms. Finally, regarding intercultural education projects mediated by the use of technologies, Tonkin and Coudray (2016) warn that students' concentration on online interaction may disconnect them from the very experiences which educators wish them to reflect on.

\subsection{Conclusion}

The goal of this review was to track the progress, if any, in the use and operationalization of the term 'intercultural education' in representative literature of the last two decades (2000-2019). The most salient finding was that there is a significant tendency towards different operationalizations of intercultural education after 2015, not limited to static concepts such as intercultural competence, but expanded towards learning 
and dialogue as dynamic and interdependent constructs: the more one engages in meaningful interaction with others, the more (s)he learns about oneself and the others; and the more one learns and reflects about his/her own learning, the more eager (s)he is to engage in genuine intercultural dialogue (with a focus on the 'inter' aspects of the interaction, such as mutuality, reciprocity, and responsiveness). This marked shift from a static, de facto view of intercultural education as a competence to deal with other cultures, towards a more dynamic, etic, culture-transcending perspective of intercultural education is highly significant. First, it shows how the recent reality of the new waves of immigration due to the Middle East crisis is reflected on actual challenges that educational systems face, in particular when it regards an 'alwaysin-the-making' citizenship education (Rapanta et al. 2020). Second, it highlights the importance of cultural literacy as "an indispensable tool for transcending the clash of ignorances (...) as part of a broad toolkit of worldviews, attitudes and competences that young people acquire for their lifelong journey" (UNESCO 2009, 118).

This new conceptualization of intercultural education based on an awareness development during intercultural learning experiences places attention on the fact that cultural diversity and internationalization per se are not enough for intercultural learning and dialogue to occur (Otten 2003). On the contrary, as our review showed, many times it is the national educational system, and with that, the way teaching and learning is perceived, that poses obstacles for authentic dialogue to occur. To add to this challenge, adopting an action-oriented perspective to interculturalism further implies that all education is potentially intercultural, when it addresses interaction, inclusion, or integration (Faas 2010). This tension between the official discourse about intercultural education, on one hand, and its actual implementation and operationalization in the classroom practice, on the other, is not to ignore, and, in fact, it emerged from the present review as well, as explained below.

First, the transformational aspects of experiential, intercultural learning are mainly assessed through self-reporting methods (e.g. reflective narratives, interviews), and not through more dynamic ways of assessment, such as interactional analysis over a period of time. This limitation is also observed by Borghetti et al. (2015) who argue that when intercultural learning is explored through interviews or questionnaires after a particular event (e.g. a class, a stay abroad, an intercultural encounter), there is the risk that participants forget or tend to justify what they have been doing and why during their interaction with the objective or subjective cultures. The second major space of improvement for intercultural education research is related to this distinction between cultures, still limited to the national level, when what is supposed to be studied are the "different and multiple identity subjectivities" (Trovão 2012, 263) that every individual carries with them. Although a few studies focus on the intrapersonal aspects of cultural literacy development (e.g. Bedekovic 2017; Børhaug and Weringer 2019; Brooks and Pitts 2016; Varga-Dobai 2018), a gap in the study of the dynamic aspects of cultural literacy and how it is developed through dialogue with any others is observed. Moreover, addressing otherness only in relation to differences in ethnical identities entails the risk of reinforcing stereotypes and prejudices (Catarci 2014; Muller-Mirza 2011). 
This gap in existing intercultural education initiatives is addressed by the DIALLS project. Rather than drawing on definitions about what intercultural education and dialogue should look like, DIALLS promotes the view of cultural literacy as an always-in-the-making dialogue praxis (Maine et al. 2019; Rapanta et al. 2020). This is achieved through the implementation of a pedagogy that promotes genuine dialogue and constructive argumentation, where all viewpoints, and subsequently the cultural subjectivities expressed within, are equally welcome and encouraged to be expressed.

\section{References}

Allan, M. 2003. Frontier crossings: Cultural dissonance, intercultural learning and the multicultural personality. Journal of Research in International Education 2: 83-110.

Allmen, M.R.-V. 2011. The intercultural perspective and its development through cooperation with the Council of Europe. In Intercultural and multicultural education: Enhancing global interconnectedness, ed. C.A. Grant and A. Portela, 33-48. New York: Routledge.

Ari, L.L., and D. Laron. 2014. Intercultural learning in graduate studies at an Israeli college of education: Attitudes toward multiculturalism among Jewish and Arab students. Higher Education 68: 243-262.

Baraldi, C. 2012. Intercultural education and communication in second language interactions. Intercultural Education 23: 297-311.

Barrett, M. 2012. Intercultural competence. EWC Statement Series, 2nd issue (23-27). Oslo: European Wergeland Centre.

Bedeković, V. 2017. Intercultural education in the function of the European values promotion. Informatologia 50: 74-86.

Bennett, M. 1993. Towards ethnorelativism: A development model of intercultural sensitivity. In Education for the intercultural experience, ed. M. Paige, 21-71. Yarmouth: Intercultural Press.

Bennett, M. 2009. Defining, measuring, and facilitating intercultural learning: A conceptual introduction to the Intercultural Education double supplement. Intercultural Education 20: S1-S13.

Borghetti, C., A. Beaven, and R. Pugliese. 2015. Interactions among future study abroad students: Exploring potential intercultural learning sequences. Intercultural Education 26: 31-48.

Børhaug, B.F., and S. Weyringer. 2019. Developing critical and empathic capabilities in intercultural education through the VaKE approach. Intercultural Education 30: 1-14.

Bozdağ, Ç. 2018. Intercultural learning in schools through telecollaboration? A critical case study of eTwinning between Turkey and Germany. International Communication Gazette 80: 677-694.

Brooks, C.F., and M.J. Pitts. 2016. Communication and identity management in a globally-connected classroom: An online international and intercultural learning experience. Journal of International and Intercultural Communication 9: 52-68.

Buber, M. 1955. Between man and man, trans, by Ronald Gregor Smith. Boston: Beacon Press.

Busse, V., and U.M. Krause. 2015. Addressing cultural diversity: Effects of a problem-based intercultural learning unit. Learning Environments Research 18: 425-452.

Byram, M. 1997. Teaching and assessing intercultural communicative competence. Clevedon: Multilingual Matters.

Byram, M. 2012. Conceptualizing intercultural (communicative) competence and intercultural citizenship. In The Routledge handbook of language and intercultural communication, ed. J. Jackson, 85-98. London: Routledge.

Campbell, C.J., and C. Walta. 2015. Maximising intercultural learning in short term international placements: Findings associated with orientation programs, guided reflection and immersion. Australian Journal of Teacher Education. https://doi.org/10.14221/ajte.2015v40n10.1. 
Catarci, M. 2014. Intercultural education in the European context: Key remarks from a comparative study. Intercultural Education 25: 95-104.

Chan, E.A., T. Lai, A. Wong, S. Ho, B. Chan, M. Stenberg, and E. Carlson. 2017. Nursing students' intercultural learning via internationalization at home: A qualitative descriptive study. Nurse Education Today 52: 34-39.

Chao, T.C. 2013. A diary study of university EFL learners' intercultural learning through foreign films. Language, Culture and Curriculum 26: 247-265.

Cloonan, A., B. Fox, S. Ohi, and C. Halse. 2017. An analysis of the use of autobiographical narrative for teachers' intercultural learning. Teaching Education 28: 131-144.

Cope, B. and M. Kalantzis. 2009. "Multiliteracies": New literacies, new learning. Pedagogies: An International Journal 4: 164-195.

Council of Europe. 2008. White paper on intercultural dialogue: Living together as equals in dignity. Strasbourg: Council of Europe.

Dai, K., and J. Garcia. 2019. Intercultural learning in transnational articulation programs: The hidden agenda of Chinese students' experiences. Journal of International Students 9: 362-383.

Deardorff, D.K. 2006. Identification and assessment of intercultural competence as a student outcome of internationalization. Journal of Studies in International Education 10: 241-266.

Donelan, K. 2010. Drama as intercultural education: An ethnographic study of an intercultural performance project in a secondary school. Youth Theatre Journal 24: 19-33.

Dorsett, P., S. Larmar., and J. Clark. 2019. Transformative intercultural learning: A short-term international study tour. Journal of Social Work Education 55: 565-578.

European Commission. n.d. Intercultural dialogue. https://ec.europa.eu/culture/policy/strategic-fra mework/intercultural-dialogue_en. Accessed 22 June 2020.

Faas, D. 2010. Negotiating political identities: Multiethnic schools and youth in Europe. Farnham: Ashgate.

Frimberger, K. 2016. A Brechtian theatre pedagogy for intercultural education research. Language and Intercultural Communication 16: 130-147.

Gill, S. 2007. Overseas students' intercultural adaptation as intercultural learning: A transformative framework. Compare 37: 167-183.

Grimminger-Seidensticker, E., and A. Möhwald. 2017. Intercultural education in physical education: Results of a quasi-experimental intervention study with secondary school students. Physical Education and Sport Pedagogy 22: 445-458.

Gropas, R., and A. Triandafyllidou. 2011. Greek education policy and the challenge of migration: An 'intercultural' view of assimilation. Race Ethnicity and Education 14: 399-419.

Hadjisoteriou, C., D. Faas, and P. Angelides. 2015. The Europeanisation of intercultural education? Responses from EU policy-makers. Educational Review 67: 218-235.

Hajisoteriou, C., and P. Angelides. 2017. Collaborative art-making for reducing marginalisation and promoting intercultural education and inclusion. International Journal of Inclusive Education 21: 361-375.

Hammer, M.R., M. Bennett, and R. Wiseman. 2003. Measuring intercultural sensitivity: The intercultural development inventory. International Journal of Intercultural Relations 27: 421-443.

Hepple, E., J. Alford, D. Henderson, D. Tangen, M. Hurwood, A. Alwi, ... and A. Alwi. 2017. Developing intercultural learning in Australian pre-service teachers through participating in a short term mobility program in Malaysia. Teaching and Teacher Education 66: 273-281.

Hernández-Bravo, J.A., M.C. Cardona-Moltó, and J.R. Hernández-Bravo. 2017. Developing elementary school students' intercultural competence through teacher-led tutoring action plans on intercultural education. Intercultural Education 28: 20-38.

Hessel, G. 2019. The role of international student interactions in English as a lingua franca in L2 acquisition, L2 motivational development and intercultural learning during study abroad. Studies in Second Language Learning and Teaching 9: 495-517.

Holmes, P., L. Bavieri, and S. Ganassin. 2015. Developing intercultural understanding for study abroad: Students' and teachers' perspectives on pre-departure intercultural learning. Intercultural Education 26: 16-30. 
Hyett, N., K. Lee, R. Knevel, T. Fortune, M. Yau, and S. Borkovic. 2019. Trialing virtual intercultural learning with Australian and Hong Kong allied health students to improve cultural competency. Journal of Studies in International Education 23: 389-406.

Jin, L., and M. Cortazzi. 2013. Researching intercultural learning. Hampshire: Palgrave Macmillan. Kesckes, I. 2014. Intercultural pragmatics. Oxford: Oxford University Press.

King, P.M., R.J. Perez, and W.J. Shim. 2013. How college students experience intercultural learning: Key features and approaches. Journal of Diversity in Higher Education 6: 69-83.

Kolb, D.A. 2015. Experiential learning, 2nd ed. New Jersey: Pearson Education.

Lähdesmäki, T., A.K. Koistinen, and S. Ylönen. 2020. Intercultural dialogue in the European education policies: A conceptual approach. Cham: Palgrave Macmillan.

Lau, S.M. 2015. Intercultural education through a bilingual children's rights project: Reflections on its possibilities and challenges with young learners. Intercultural Education 26: 469-482.

Leclercq, J.M. 2002. The lessons of thirty years of European co-operation for intercultural education. Strasbourg: Steering Committee for Education.

Lee, L. 2012. Engaging study abroad students in intercultural learning through blogging and ethnographic interviews. Foreign Language Annals 45: 7-21.

Maine, F., V. Cook, and T. Lähdesmäki. 2019. Reconceptualizing cultural literacy as a dialogic practice. London Review of Education 17: 383-392.

Martin, F., and H. Griffiths. 2014. Relating to the 'other': Transformative, intercultural learning in post-colonial contexts. Compare 44: 938-959.

Mesker, P., H. Wassink, S. Akkerman, and C. Bakker. 2018. Differences that matter: Boundary experiences in student teachers' intercultural learning. International Journal of Intercultural Relations 64: 54-66.

Mezirow, J. 2000. Learning as transformation-Critical perspectives on a theory in progress. San Francisco: Jossey-Bass.

Mitchell, L., and A. Paras. 2018. When difference creates dissonance: Understanding the 'engine' of intercultural learning in study abroad. Intercultural Education 29: 321-339.

Mirza, N.M. 2011. Civic education and intercultural issues in Switzerland: Psychosocial dimensions of an education to "otherness." Journal of Social Science Education 10: 31-40.

O'Brien, B., D. Tuohy, A. Fahy, and K. Markey. 2019. Home students' experiences of intercultural learning: A qualitative descriptive design. Nurse Education Today 74: 25-30.

O'Connor, C., and S. Michaels. 2007. When is dialogue 'dialogic'? Human Development 50: 275 285.

O'Dowd, R. 2003. Understanding the "other side": Intercultural learning in a Spanish-English e-mail exchange. Language Learning \& Technology 7: 118-144.

Otten, M. 2003. Intercultural learning and diversity in higher education. Journal of Studies in International Education 7: 12-26.

Piipponen, O., and L. Karlsson. 2019. Children encountering each other through storytelling: Promoting intercultural learning in schools. The Journal of Educational Research 112: 590-603.

Portera, A. 2008. Intercultural education in Europe: Epistemological and semantic aspects. Intercultural Education 19: 481-491.

Rapanta, C., M. Vrikki, and M. Evagorou. 2020. Preparing culturally literate citizens through dialogue and argumentation: Rethinking citizenship education. The Curriculum Journal. https:// doi.org/10.1002/curj.95.

Santos, M., and H. Araújo e Sá, and A. Simões . 2014. Intercultural education in primary school: A collaborative project. Language and Intercultural Communication 14: 140-150.

Senyshyn, R. 2018. Teaching for transformation: Converting the intercultural experience of preservice teachers into intercultural learning. Intercultural Education 29: 163-184.

Sfard, A. 2008. On two metaphors for learning and the dangers of choosing just one. In Knowledge and practice: Representations and identities, ed. P. Murphy and R. McCormick, 30-45. Milton Keynes: The Open University. 
Tonkin, K., and C.B.D. Coudray. 2016. Not blogging, drinking: Peer learning, sociality and intercultural learning in study abroad. Journal of Research in International Education 15: 106-119.

Triandis, H.C. 1994. Culture and social behaviour. New York: McGraw-Hill.

Trovão, S. 2012. Comparing postcolonial identity formations: Legacies of Portuguese and British colonialisms in East Africa. Social Identities 18: 261-280.

UNESCO. 2009. World report: Investing in cultural diversity and intercultural dialogue. Paris: UNESCO. Available at: https://en.unesco.org/interculturaldialogue/resources/130.

Varga-Dobai, K. 2018. Remixing selfies: Arts-based explorations of funds of knowledge, meaningmaking, and intercultural learning in literacy. International Journal of Multicultural Education 20: $117-132$.

Wells, G. 2007. Semiotic mediation, dialogue and the construction of knowledge. Human Development 50: 244-274.

Wilbur, G. 2016. The staying power of intercultural learning through reflective inquiry. Reflective Practice 17: 59-71.

Chrysi Rapanta (PhD Communication Sciences, University of Lugano, Switzerland) is a Senior Researcher at NOVA University Lisbon, Faculty of Social and Human Sciences, where she also teaches Intercultural communication and Social science methods courses. She has experience in the field of Argumentation and Education.

Susana Trovão (PhD Anthropology, Universidade Nova, Portugal) is a Full Professor of Anthropology at NOVA University Lisbon, Faculty of Social and Human Sciences. Her areas of research and expertise comprise Migrations, Inter-Ethnicities and Transnationalism.

Open Access This chapter is licensed under the terms of the Creative Commons Attribution 4.0 International License (http://creativecommons.org/licenses/by/4.0/), which permits use, sharing, adaptation, distribution and reproduction in any medium or format, as long as you give appropriate credit to the original author(s) and the source, provide a link to the Creative Commons license and indicate if changes were made.

The images or other third party material in this chapter are included in the chapter's Creative Commons license, unless indicated otherwise in a credit line to the material. If material is not included in the chapter's Creative Commons license and your intended use is not permitted by statutory regulation or exceeds the permitted use, you will need to obtain permission directly from the copyright holder. 